\title{
Deployment of Open and Distance Learning to Persevere Teaching and Learning during COVID-19 Pandemic in Malaysia
}

\author{
Faddliza MOHD ZAKI, Noor Masliana RAZLAN, Nurulannisa ABDULLAH \\ Nurhidayah NASHARUDIN, Norhidayu MD YATIM, Noor Faraliza SAMSUDIN \\ Jashira JAMIN and Intan Nurbaizura ZAINUDDIN
}

Faculty of Information Management, Universiti Teknologi MARA (UiTM)

Negeri Sembilan, Malaysia

Correspondence should be addressed to: Faddliza MOHD ZAKI; faddliza@uitm.edu.my

Received date: 2 November 2020; Accepted date: 10 February 2021; Published date: 28 July 2021

Academic Editor: Tung-Liang Chen

Copyright (C) 2021. Faddliza MOHD ZAKI, Noor Masliana RAZLAN, Nurulannisa ABDULLAH Nurhidayah NASHARUDIN, Norhidayu MD YATIM, Noor Faraliza SAMSUDIN Jashira JAMIN and Intan Nurbaizura ZAINUDDIN. Distributed under Creative Commons Attribution 4.0 International CC-BY 4.0

\begin{abstract}
Education is essential to an individual and definitely to a country in a large scale as it contributes to human development. However, when COVID-19 pandemic struck the world and the number of cases had rose sharply in 2020, it affected every sector including education sector. In Malaysia, a sudden disruption happened when all education institutions including the tertiary education institutions are closed due to Movement Control Order on March 2020 enforced by its Government. Open and Distance Learning (ODL) is an option to sustain the teaching and learning process. Thus, this study aims to identify the technological tools used by undergraduate students in ODL and identify the preferred method and platforms by them in ODL. A quantitative method was used to determine the method and platforms preferred by Library and Information Science (LIS) students during ODL in Universiti Teknologi MARA (UiTM). It was found that students were able to access the Internet either by using mobile data, Wi-Fi, or both. Furthermore, the ODL method preferred by students is video recordings/ narrations. WhatsApp is a preferred platform in receiving information from their lecturers whilst Google Classroom is an application platform to download teaching materials and assignments. The contribution of this study can be seen in terms of providing relevant data and information to the various parties especially to the lecturers and the university. It will assist them in planning and implementing the best method and platforms preferred by students.
\end{abstract}

Keywords: 1. Open and Distance Learning 2. Tertiary education 3. Technological tools

Cite this Article as: Faddliza MOHD ZAKI, Noor Masliana RAZLAN, Nurulannisa ABDULLAH Nurhidayah NASHARUDIN, Norhidayu MD YATIM, Noor Faraliza SAMSUDIN Jashira JAMIN and Intan Nurbaizura ZAINUDDIN (2021)," Deployment of Open and Distance Learning to Persevere Teaching and Learning during COVID-19 Pandemic in Malaysia' Academic Engagement", Journal of e-Learning and Higher Education, Vol. 2021 (2021), Article ID 145199, DOI: 10.5171/2021.145199 


\section{Introduction}

Open and Distance Learning (ODL) was seen as a priority for teaching and learning method used during COVID-19 pandemic as precaution actions to ensure schools and academic institutions can continue their operation in the education system. Furthermore, this pandemic is being described as a global crisis without precedent and this affects mostly the whole living system operations including the education system (Hall et al. 2020). The pandemic obviously gives impact on the tertiary education sector in Malaysia when the Government of Malaysia enforced a Movement Control Order starting on March 18, 2020 to break the chain of COVID-19 (Ain Umaira Md Shah et al. 2020). Universities themselves rapidly introduced new forms of teaching and learning, where shifts to online teaching, new forms of assessment and innovative digital communication tools are all evident (Raaper \& Brown 2020). It is obvious that ODL is mediated by technology and the Internet. Having access to both is vital for a successful teaching and learning process.

The digital technology such as desktops, laptops or smartphones can help students in ODL. However, from the research done by researchers, it was found that there are Library and Information Science (LIS) students from Universiti Teknologi MARA (UiTM) Negeri Sembilan Branch who do not participate in online studies due to technological constraints and access to the Internet. In addition, there is lack of studies conducted on the implementation of ODL particularly on how students access technology and what are the online learning method and platforms that they prefer to use during ODL involvement.

Therefore, the objectives of the study are:

1. To identify the technological tools used by students in ODL

2. To identify the preferred method and platforms by students in ODL

\section{Literature Review}

\section{Open and Distance Learning (ODL) Deployment}

Today's world challenge is a pandemic crisis. As we all know, because of the COVID19 pandemic, things are shifting and changing rapidly and the effect, enforceability and interpretation of laws may be affected by future events. (Deliu 2020). This crisis has caused a sudden interruption of schools, colleges, universities, and other government institutions to use electronic learning system (e-learning) (Soni 2020). During these extreme times, students may have short-term and long-term disruptions in their education. The Higher Education Ministry of Malaysia has announced that all teaching and learning programmes in universities should be conducted through online platform. However, these are subject to the authorities from time to time by looking at the progress of COVID-19 cases and scenarios in Malaysia. Students are allowed to be involved in the resumption of physical face-to-face teaching and learning programmes but have to prioritise safety and physical distancing measures (Landau 2020). Thus, ODL has a great contribution to educational processes today. Knowledge can be translated into a two-way online communication as a proactive partnership and at the same time ensuring one's safety and it is not necessarily to be acquired in classrooms (Bernama 2020). The pivot from in-school classroom teaching and learning to entirely distance models of education is happening right now as necessitated by the COVID 19 crisis (Doucet et al. 2020). ODL are innovations to adapt to today's world. It is a combination of open learning and distance learning. Distance education has become a norm during the pandemic of COVID-19 to sustain the educational processes when students and teachers are constraint to have a face-to-face teaching and learning. This allows the students to self-pace through the online content. There are usually no set times for distance classes (Jenkins et al. 2017). ODL is different with the concept of blended learning. Blended learning is the combination of face-to-face

Faddliza MOHD ZAKI, Noor Masliana RAZLAN, Nurulannisa ABDULLAH Nurhidayah NASHARUDIN, Norhidayu MD YATIM, Noor Faraliza SAMSUDIN Jashira JAMIN and Intan Nurbaizura ZAINUDDIN, Journal of e-Learning and Higher Education, DOI: 10.5171/2021.145199 
and online delivery where $30-60 \%$ of the course content is electronically delivered. The electronic delivery can be either asynchronous or synchronous; also sometimes termed as Hybrid Learning (Ministry of Education Malaysia 2014). In addition, blended learning is a method of teaching and learning by the combination of traditional class activities with computermediated and online instructions (Allen, Seaman \& Garrett 2007). However, the similarities between ODL and blended learning are both methods that required the students and teachers to access and use technology for teaching and learning.

\section{Technological Requirement}

Technology imposes the changes in education. It gives impact in the educational development. It moves the conventional methods to an e-learning environment that is a learning that is facilitated and supported through the use of information and communications technology (ICT). It may involve the use of some, or all, of the following technologies; namely, desktop and laptop computers, software (including assistive software), interactive whiteboards, digital cameras, mobile and wireless tools (including mobile phones), electronic communication tools (including email, discussion boards, chat facilities \& video conferencing), Virtual Learning Environments and learning activity management systems (Ministry of Education Malaysia 2014).

Students should be able to have access to technology and the Internet as these are important elements in ODL for their learning process. Thus, technology can support the ubiquitous learning and allow a combination of synchronous and asynchronous learning (Doucet et al. 2020). For effective learning, students should be allowed to choose one that suits their learning preferences or that can be personalised to their needs (Ministry of Education Malaysia 2014). Students may become bored and are quite likely to poorly perform on evaluations if learning preferences and teaching methods occasionally do not match (Litzinger et al. 2017).
Researchers have found out by an observation made on 23rd March 2020, Google Trends in Malaysia showed that the searches on 'Google Classroom', 'Zoom App' and 'Zoom Meeting' were recorded as the three highest search terms. These are online platforms that can support teaching and learning to be conducted online. There are many others available online platforms such as Googel Meet, Microsoft Teams, Loom and Google Hangouts. In addition, data collected by the Statistics Department of Malaysian Communications and Multimedia Commision (2018) highlighted that there are 28.7 million Internet users in 2018 . The average duration of daily use of Internet for the age group of 20's is 8 hours per day which made them as the highest age group that accesses the Internet. This shows that supposedly university students should not have any issues regarding on ODL teaching and learning methods. Based on previous research conducted by Aminudin, Karthikeyan and Priyadarshana (2019), a study is needed on the practices of open, distance, and online learning along with the advances in new technology and the changing needs of students. It is compulsory for students to have access to technology and the Internet during ODL. Without a stable Internet connection, the learning process will be disrupted. Furthermore, if students do not possess any learning facilities such as a laptop or a mobile phone, it is impossible to conduct the ODL for both lecturers and students and this will have an impact on the students' performance. Furthermore, the implementation of ODL requires students' engagement, motivation and interaction. Students should be required to interact with one another, with the instruction, with the content, with the entire class, in small groups or teams, oneon-one with a peer, etc. (Ministry of Education Malaysia 2014).

\section{Data Collection Methods}

This study adopts a quantitative method. A survey was used to determine the method and platforms preferred by Library and Information Science (LIS) students during ODL in UiTM for the course of 'Introduction to Cataloging'.

Faddliza MOHD ZAKI, Noor Masliana RAZLAN, Nurulannisa ABDULLAH Nurhidayah NASHARUDIN, Norhidayu MD YATIM, Noor Faraliza SAMSUDIN Jashira JAMIN and Intan Nurbaizura ZAINUDDIN, Journal of e-Learning and Higher Education, DOI: 10.5171/2021.145199 


\section{Research Design and Sample}

Students of Semester 4 from UiTM Negeri Sembilan Branch, Rembau Campus were selected as the research sample in this study. The questionnaire was sent to students who had registered for a 'Introduction to Cataloging' course (course code - IMD 223) in the semester of March 2020-July 2020.

\section{Population}

The population consisted of 92 registered students for the course of IMD223. The students' population would be able to address the research questions as they are the participants who must undergo and complete the subject for the said semester.

\section{Data Collection Instruments}

To understand the preferred online learning method and platforms in ODL required by students, an analysis has been conducted based on the data extracted from the questionnaire. All the findings were analyzed using IBM SPSS 25.0 software.

\section{Questionnaire}

The questionnaire was circulated to Semester 4 students from UiTM Negeri Sembilan Branch, Rembau Campus. The questionnaire had ten MCQs to meet the objectives of this study.

\section{Data analysis}

This study applied descriptive statistics to meet the research objectives because the respondents represent the population of Semester 4 students of IMD223 from UiTM Negeri Sembilan Branch, Rembau Campus. The descriptive statistics include frequency and percentage analysis, crosstabulation table and bar chart to identify students' preferred online learning method and platforms in ODL.

Frequency Analysis

This study employed primary data from 92 respondents of Semester 4 students of
IMD223 from UiTM Negeri Sembilan Branch, Rembau Campus. Table 1 shows the summary of data analysis for this study. There are 43 male students (46.7\%) and 49 female students $(53.3 \%)$ involved in this study.

Results found that more than half of the students live in city which are 62 students (67.4\%) while only 30 students (32.6\%) live in rural area when ODL was implemented. This analysis finds out that the majority of the students have their own desktop or laptop ( $\mathrm{n}=89,96.7 \%)$ and only 3 students $(3.3 \%)$ do not have any desktop or laptop. The 3 students (3.3\%) that do not have any desktop or laptop used their smartphone for ODL.

For the category of Internet access, 55 students (59.8\%) used their mobile data, 15 students (16.3\%) used Wi-Fi and 22 students used both of mobile data and Wi-Fi as their Internet access. Table 1 also reveals that 45 students (48.9\%) prefer live lectures or discussions as the ODL method while another 47 students (51.1\%) prefer video recordings or narrations. Most of the students prefer video recordings or narrations as ODL method compared to live lectures or discussions. The students that choose live lecturers or discussions as their ODL method reveals that their most preferred platform application is Google Meet $(\mathrm{n}=36,80 \%)$, Zoom $(\mathrm{n}=7,15.6 \%)$, Facebook ( $\mathrm{n}=1,2.2 \%)$ and Discord $(\mathrm{n}=1$, $2.2 \%)$.

The most convenient application of platform preferred by students when receiving information from lecturers is WhatsApp application which is preferred by 62 students $(67.4 \%)$, followed by 20 students (21.7\%) who prefer Google Classroom, 7 students (7.6\%) prefer Telegram, 2 students (2.2\%) prefer E-mail and only $1(1.1 \%)$ student prefers I-Learn/ uFuture (an online learning platform in UiTM). Meanwhile, the most convenient application of platform that preferred by students to download the teaching materials and assignments is Google Classroom which is preferred by 34 students (37.0\%), followed by 28 students (30.4\%) who prefer WhatsApp application,

Faddliza MOHD ZAKI, Noor Masliana RAZLAN, Nurulannisa ABDULLAH Nurhidayah NASHARUDIN, Norhidayu MD YATIM, Noor Faraliza SAMSUDIN Jashira JAMIN and Intan Nurbaizura ZAINUDDIN, Journal of e-Learning and Higher Education, DOI: 10.5171/2021.145199 
12 students (13.0\%) prefer E-mail, 11 students $(12.0 \%)$ prefer Telegram and only 7 students (7.6\%) prefer I-Learn/ uFuture. For the category of students who received the "B40 - Internet Allowance", more than half of students ( $n=47,51.1 \%)$ did not receive this allowance, while another 45 students (48.9\%) received the "B40 Internet Allowance".

Table 1: Summary of Data Analysis

\begin{tabular}{|c|c|c|}
\hline Items & $\begin{array}{c}\text { Frequency } \\
(\mathrm{N}=92)\end{array}$ & Percentage (\%) \\
\hline Gender & $\begin{array}{l}43 \\
49\end{array}$ & $\begin{array}{l}46.7 \\
53.3\end{array}$ \\
\hline $\begin{array}{rr}\text { Where do you live during ODL implementation? } & \\
\text { City } \\
\text { Rural }\end{array}$ & $\begin{array}{l}62 \\
30\end{array}$ & $\begin{array}{l}67.4 \\
32.6\end{array}$ \\
\hline $\begin{array}{l}\text { Do you have any desktop or laptop? } \\
\text { Yes } \\
\text { No } \\
\begin{array}{l}\text { How do you complete assignment that will be } \\
\text { given by lecturer if you choose 'No' answer for } \\
\text { question before? }\end{array} \\
\text { Smartphone }\end{array}$ & $\begin{array}{c}89 \\
3\end{array}$ & $\begin{array}{c}96.7 \\
3.3\end{array}$ \\
\hline $\begin{array}{rr}\text { What kind of Internet access do you use? } & \\
\text { Mobile Data } \\
\text { Wifi } \\
\text { Both }\end{array}$ & $\begin{array}{l}55 \\
15 \\
22\end{array}$ & $\begin{array}{l}59.8 \\
16.3 \\
23.9\end{array}$ \\
\hline $\begin{array}{l}\text { What is you preferred method for ODL? If your answer } \\
\text { is 'Live lectures/ discussions', please answer next } \\
\text { question. } \\
\text { Live Lectures / Discussions } \\
\text { Video Recordings / Narrations } \\
\text { i. What is your most preferred application of } \\
\text { platform? } \\
\text { Google Meet } \\
\text { Zoom } \\
\text { Discord } \\
\text { Facebook }\end{array}$ & $\begin{array}{c}36 \\
7 \\
1 \\
1\end{array}$ & $\begin{array}{c}48.9 \\
51.1 \\
\\
\\
80.0 \\
15.6 \\
2.2 \\
2.2\end{array}$ \\
\hline $\begin{array}{r}\text { What is the most convenient application or platform you } \\
\text { prefer in receiving information by lecturers? } \\
\text { WhatsApp } \\
\text { E-mail } \\
\text { Google Classroom } \\
\text { Telegram } \\
\text { I-Learn / uFuture }\end{array}$ & $\begin{array}{c}62 \\
2 \\
20 \\
7 \\
1\end{array}$ & $\begin{array}{c}67.4 \\
2.2 \\
21.7 \\
7.6 \\
1.1\end{array}$ \\
\hline $\begin{array}{l}\text { What is the most convenient application or platform you } \\
\text { prefer to download the teaching materials and } \\
\text { assignments? } \\
\text { WhatsApp } \\
\text { E-mail } \\
\text { Google Classroom } \\
\text { Telegram }\end{array}$ & $\begin{array}{l}28 \\
12 \\
34 \\
11\end{array}$ & $\begin{array}{l}30.4 \\
13.0 \\
37.0 \\
12.0\end{array}$ \\
\hline
\end{tabular}

Faddliza MOHD ZAKI, Noor Masliana RAZLAN, Nurulannisa ABDULLAH Nurhidayah NASHARUDIN, Norhidayu MD YATIM, Noor Faraliza SAMSUDIN Jashira JAMIN and Intan Nurbaizura ZAINUDDIN, Journal of e-Learning and Higher Education, DOI: 10.5171/2021.145199 


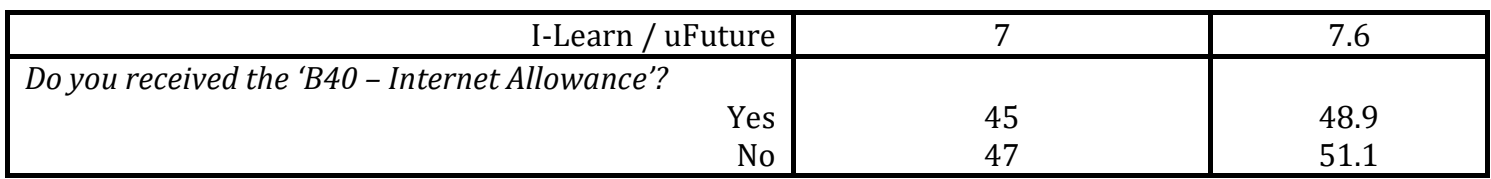

\section{Crosstabs Analysis}

Table 2 shows the cross-tabulation table of students' location during ODL implementation with preferred method of ODL among Semester 4 students of IMD223 from UiTM Negeri Sembilan, Rembau Campus. The crosstabs table below reveals that $51.1 \%$ students $(n=47)$ prefer video recordings/ narrations and $48.9 \%$ students $(n=45)$ prefer live lectures/ discussions as the ODL method. Based on the fact that $51.1 \%$ students $(\mathrm{n}=47)$ prefer video recordings / narrations as the ODL method, there are $57.4 \%(n=27)$ from city area and $42.6 \%(n=20)$ from rural area. Meanwhile the other $48.9 \%$ students $(n=45)$ prefer live lectures/ discussions as the ODL method, which comes from $77.8 \%(\mathrm{n}=35)$ city area students and $22.2 \%(\mathrm{n}=10)$ rural area students.

Table 2: Live Lectures vs Video Recordings

\begin{tabular}{|r|c|c|c|}
\hline \multirow{2}{*}{$\begin{array}{l}\text { Location during ODL } \\
\text { Implementation }\end{array}$} & \multicolumn{2}{|c|}{ Preferred Method of ODL } & \multirow{2}{*}{ Total } \\
\cline { 2 - 4 } & Live lectures/Discussions & Video Recodings/Narrations & \\
\hline City & 35 & 27 & $\mathbf{6 2}$ \\
& $(77.8 \%)$ & $(57.4 \%)$ & $\mathbf{( 6 7 . 4 \% )}$ \\
\hline Rural Area & 10 & 20 & $\mathbf{3 0}$ \\
& $(22.2 \%)$ & $(42.6 \%)$ & \\
\hline Total & $\mathbf{4 5 ( 4 8 . 9 \% )}$ & $\mathbf{4 7}(\mathbf{5 1 . 1 \% )}$ & \\
\hline
\end{tabular}

By referring to Table 3, the cross-tabulation table of Internet access with preferred method of ODL among Semester 4 students of IMD223 from UiTM Negeri Sembilan Branch, Rembau Campus, shows that 51.5\% students ( $\mathrm{n}=47)$ who choose video recordings/ narrations as ODL method can access the Internet through mobile data which are $72.3 \%$ of students $(n=34), 14.9 \%$ ( $\mathrm{n}=7$ ) students can access through Wi-Fi and $12.8 \%$ students $(n=6)$ access through both mobile data and Wi-Fi. While the other $48.9 \%$ students $(n=45)$ that chose live lectures/ discussions as ODL method, they access the Internet through mobile data which are $46.7 \%$ of students $(n=21), 17.8 \%$ ( $\mathrm{n}=8$ ) students can access through $\mathrm{Wi}-\mathrm{Fi}$ and $35.6 \%$ students $(n=16)$ access through both mobile data and $\mathrm{Wi}-\mathrm{Fi}$.

Table 3: Internet Access vs ODL Method

\begin{tabular}{|r|c|c|c|}
\hline \multirow{2}{*}{ Internet Access } & \multicolumn{2}{|c|}{ Preferred Method of ODL } & \multirow{2}{*}{ Total } \\
\cline { 2 - 4 } & Live lectures/Discussions & Video Recodings/Narrations & $\mathbf{5 5}$ \\
\hline Mobile Data & 21 & 34 & $(\mathbf{5 9 . 8 \% )}$ \\
\hline Wi-Fi & $(46.7 \%)$ & $7.3 \%)$ & $\mathbf{1 5}$ \\
& $(17.8 \%)$ & $(14.9 \%)$ & $\mathbf{2 2}$ \\
\hline Both & 16 & 6 & $(\mathbf{2 3 . 9} \%)$ \\
\hline Total & $(35.6 \%)$ & $(12.8 \%)$ & \\
\hline
\end{tabular}

Faddliza MOHD ZAKI, Noor Masliana RAZLAN, Nurulannisa ABDULLAH Nurhidayah NASHARUDIN, Norhidayu MD YATIM, Noor Faraliza SAMSUDIN Jashira JAMIN and Intan Nurbaizura ZAINUDDIN, Journal of e-Learning and Higher Education, DOI: 10.5171/2021.145199 


\section{Discussions}

\section{Respondents Demographic Profile}

According to Table 1, the total percentages of female students are higher than male students because the overall population of female students in the campus is bigger than that of male students. This finding is supported by the National Center for Education Statistics (2020) that stated the enrollment numbers of female students are higher than male students in American academic institutions since few years ago. Besides that, the percentage of students who live in the city area is higher than students who live in the rural area probably because some students who live in the rural area have moved to urban areas by staying at relatives' houses to get better Internet facilities during ODL implementation. According to The Star (2020), some students, especially those living on islands and plantations, do not have efficient Internet access, apart from not having facilities like computers, smartphones or other mobile devices that can facilitate the delivery process of online teaching and facilitation (PdPc) sessions.

\section{Research Objective 1: To identify the technological tools used by students in ODL}

The result demonstrates that $96.7 \%$ of students have their own desktop or laptop for ODL. Students preferred to have desktop or laptop because desktop computers are more powerful with many features, convenient keyboard, easy to use with mouse and have larger monitors. Besides that, laptop computers are highly portable and allow users to use the computer almost anywhere (England.edu 2020). However, there are $3.3 \%$ students only who have had smartphone during ODL implementation. Smartphone is not preferred by students for ODL because of the unstable Internet connectivity, and the size of the screen and keypad which makes smartphone not convenient for learning. Besides that, smartphone did not support some file/ format, hang during important learning moments, intruding the learning sessions with incoming calls and the issue of a constant draining batteries.

In terms of the Internet resources, half of the respondents prefer using mobile data than Wi-Fi because the former is more convenient. When using mobile data, students do not have to depends on a desktop or laptop with the Internet connection. All they need is just a smartphone with mobile data that supports the Internet connection. Therefore, accessing the Internet is hassle free and easy. Moreover, files and documents can be easily downloaded on their phones. Notes, assessments and other online learning contents can be downloaded online; emails can be read and sent anytime and anywhere. Apart from that, students do not have to install any software repeatedly. All they need is the Internet recharge cards. They just have to buy the cards and instantly can access the Internet. Students can also subscribe for $3 \mathrm{G}$ or $4 \mathrm{G}$ Internet data plan at a lower price in the market.

\section{Research Objective 2: To identify the preferred method and platforms by} students in $O D L$

From the analysis, it can be concluded that video recordings/ narrations are the most preferred ODL method among Semester 4 students of IMD223 from UiTM Negeri Sembilan Branch, Rembau Campus. Video recordings of lectures offer various benefits to the user (Nieder, Borges \& Pearson 2011). Students can repeat the lecture subsequently at any time and place. They might gain time because the way to the lecture hall is no longer necessary (Spickard et al. 2002). For students who were convenient with live lectures/ discussions, the preferred platform they choose to use is Google Meet rather than Zoom, Facebook and Discord. Students were comfortable if the lecturers use Google Meet in delivering their subject contents since Google Meet gives personal connection that is missing from face-to-face class time. Furthermore, it helps students to communicate more clearly with facial expressions, body language and intonation, and pushing record and talking

Faddliza MOHD ZAKI, Noor Masliana RAZLAN, Nurulannisa ABDULLAH Nurhidayah NASHARUDIN, Norhidayu MD YATIM, Noor Faraliza SAMSUDIN Jashira JAMIN and Intan Nurbaizura ZAINUDDIN, Journal of e-Learning and Higher Education, DOI: 10.5171/2021.145199 
can be much faster than other forms of communication.

The most convenient application or platform chosen by students when receiving any information from lecturers is the WhatsApp application. There is a research study done by Spickard et al. (2002) that highlighted that WhatsApp is a free messenger application that works across multiple platforms like iPhone and android phones, and this application is being widely used among undergraduate students to send multimedia messages like photos, videos, audios along with simple text messages. Moreover, as mentioned by Fogg (2008), since the Internet facility is required for using WhatsApp, lots of information can also be accessed in real time and sharing that information through technology is both instantaneous and convenient. In addition, WhatsApp messenger has the following collaborative features such as multimedia, group chat, unlimited messaging, cross platform engagements, offline messaging, no charges involved, pins and users' names (Bere, 2012).

Meanwhile the most convenient application of platform that is preferred by students to download the teaching materials and assignments is Google Classroom. As stated by My e-Learning World (2020), the Google Classroom is a tool to facilitate instructorlearner communication and ensure easy feedback and smooth document sharing. The system guides both students and teachers through the process gently with the use of push notifications and emails. The learning tool is able to alert students to receive assignments and turn them in on time.

\section{Conclusion}

The study has investigated and identified the LIS students' online learning method and platforms preferences during ODL specifically on students of Semester 4 who had registered for 'Introduction to Cataloging' course (course code - IMD 223) for the semester of March - July 2020 in UiTM Negeri Sembilan Branch, Rembau Campus. The investigation led to identifying the technology tools used by the students and their preferred method and platforms used during ODL since not all students were involved in online studies due to technological constraints and access to the Internet.

The study has contributed to the understanding of the usage and effectiveness of teaching and learning method used during COVID-19 pandemic as precaution actions to ensure schools and academic institutions can continue their operation in the education system. The finding proved that students were able to access the Internet either by using mobile data, Wi-Fi or both. This shows that accessing the Internet is not an issue for students as they are able to be connected online. Besides that, ODL method preferred by students is video recordings/ narrations as this method allows students to have a flexible learning whereby they can learn ubiquitously and at any time. For students who preferred live lectures/ discussions, the platform that they opt for is Google Meet. Students also preferred WhatsApp as the platform for receiving information from their lecturers and Google Classroom as an application platform to download teaching materials and assignments.

The contribution of this study can be seen in terms of providing relevant data and information to the various parties especially to the lecturers and the university. The university must have a comprehensive ODL policy to meet the needs of students and lecturers. A lot of training programs should be conducted to enrich lecturers with enough knowledge and skills to ensure ODL can be delivered successfully. In international educational circles, there has long been a call for "Maslow before Bloom" (Doucet et al. 2020), which argues that students' basic needs must be met before academic learning can be fully embraced. Furthermore, according to Everett (2015), engaging students in learning is important to ensure persistence and improves academic achievement. Therefore, identifying students' conditions and preferences for ODL may assist lecturers and universities all around the world towards a successful teaching and learning

Faddliza MOHD ZAKI, Noor Masliana RAZLAN, Nurulannisa ABDULLAH Nurhidayah NASHARUDIN, Norhidayu MD YATIM, Noor Faraliza SAMSUDIN Jashira JAMIN and Intan Nurbaizura ZAINUDDIN, Journal of e-Learning and Higher Education, DOI: 10.5171/2021.145199 
process. Last but not least, it is obvious that other universities that are implementing ODL can use the findings from this study to structure an effective policy and plan to ensure the success of ODL in their institutions that can improve the online teaching and learning process.

\section{References}

- Ain Umaira Md Shah, Syafiqah Nur Azrie Safri, Thevadas, R, Nor Kamariah Noordin, Azmawani Abd Rahman, Zamberi Sekawi et al. (2020), 'COVID19 Outbreak in Malaysia: Actions Taken by the Malaysian Government,' International Journal of Infectious Diseases, 97, 108-116.

- Allen, IE., Seaman, J. and Garrett, R. (2007), 'Blending in: The extent and promise of blended education in the United States,' [Online], [Retrieved October 20,2020],

https://www.onlinelearningsurvey.co $\mathrm{m} /$ reports/blending-in.pdf

- Aminudin Zuhairi, Karthikeyan, N. and Priyadarshana, ST. (2019), 'Supporting Students to Succeed in Open and Distance Learning in Open University of Sri Lanka and Universitas Terbuka Indonesia,' Asian Association of Open Universities Journal, 15 (1).

- $\quad$ Bere, A. (2012), 'A comparative study of student experiences of ubiquitous learning via mobile devices and learner management systems at a South African university' Proceedings of the 14th Annual Conference on World Wide Web Applications, 7-9 November, 2012. Durban, Cape Peninsula University of Technology.

- Bernama. (2020), 'Teachers face big challenge in Sabah's rural areas to carry out online learning,' The Star. [Online], [Retrieved April 25, 2020], https://www.thestar.com.my/news/n ation/2020/04/25/teachers-face-bigchallenge-in-sabah039s-rural-areas-tocarry-out-online-learning

- Clow, D. (2020), 'What should universities do to prepare for COVID-19 corona virus?' [Online], [Retrieved October 15, 2020], https://wonkhe.com/blogs/what- should-universities-do-to-prepare-forcovid-19-coronavirus/

- Clune, A. (2020), 'Using technology to cope with Covid-19 on (or off) campus,' [Online], [Retrieved October 15, 2020], https://wonkhe.com/blogs/usingtechnology-to-cope-with-covid-19-onor-off-campus/

- Google Trends. (2020), 'Daily search trends: Malaysia,' [Online], [Retrieved March 23, 2020], https://trends.google.com.my/trends/ trendingsearches/daily?geo=MY

- Darko-Adjei, N. (2019), 'The Use and Effect of Smartphones in Students' Learning Activities: Evidence from the University of Ghana, Legon,' Library Philosophy and Practice (e-journal). [Online], [Retrieved September 19, 2020],

https://digitalcommons.unl.edu/libphi lprac/285

- Dayığlu, M and Türüt-Așik, S. (2007), 'Gender Differences in Academic Performance in a Large Public University in Turkey,' Higher Education 53 (2), 255-277.

- Deliu, D. (2020), 'The impact of a socioeconomic crisis on corporate governance effectiveness and sustainable development. Acumen: The current new Coronavirus (Covid-19) pandemic' Proceedings of the 35th International Business Information Management Association (IBIMA), 1-2 April 2020, Seville, Spain.

- Doucet, A., Netolicky, D., Timmers, K. and Tuscano, F.J. (2020), 'Thinking about pedagogy in an unfolding pandemic: An independent report on approaches to distance learning during COVID19,' [Online], [Retrieved October 15, 2020], https://www.oitcinterfor.org/sites/de fault/files/file_publicacion/2020_Rese arch_COVID-19.pdf

- England.edu. (2020), 'Laptop VS desktop computer,' [Online], [Retrieved October 24, 2020], https://england.edu/bookstore/laptop-vs-desktop-computer/

- Everett, DR. (2015), 'Adding Value: Online Student Engagement,' Information Systems Education Journal, $13(6), 68-76$.

Faddliza MOHD ZAKI, Noor Masliana RAZLAN, Nurulannisa ABDULLAH Nurhidayah NASHARUDIN, Norhidayu MD YATIM, Noor Faraliza SAMSUDIN Jashira JAMIN and Intan Nurbaizura ZAINUDDIN, Journal of e-Learning and Higher Education, DOI: 10.5171/2021.145199 
- Fogg, P. (2008), 'The 24-7 ProfessorWhat to Do When Home is Just Another Word for the Office.' Chronicle of Higher Education, 54 (21), 12.

- Hall, T., Connolly, C., Gradaigh, SO., Burden, K., Kearney, M., Schuck, S. et al. (2020), 'Education in precarious times: A comparative study across six countries to identify design priorities for mobile learning in pandemic,' Information and Learning Science. [Online], [Retrieved September 19, 2020], http://doi.org/ 10.1108/ILS-042020-0089

- Jenkins, J., Rumble, G., Murugan, K., Koul, B., Dodds, T., Peters, O. et al. (2017), 'Unit-9 Characteristics of Distance Education,'.

- Landau, E. (2020), 'University lectures to go online until Dec 31, except for 5 groups,' New Straits Times. [Online], [Retrieved May 27, 2020], https://www.nst.com.my/news/natio n/2020/05/595758/universitylectures-go-online-until-dec-31except-5-groups

- Lederman, D. (2020), 'Evaluating teaching during the pandemic,' [Online], [Retrieved October 24, 2020], https://www.insidehighered.com/digi tal-

learning/article/2020/04/08/manycolleges- are-abandoning-ordowngrading-student-evaluations.

- $\quad$ Litzinger, TA., Lee, SH., Wise, JC. and Felder, RM. (2007), 'A Psychometric Study of the Index of Learning Styles,' Journal of Engineering Education, 96 (4), 309-319.

- Malaysian Communications and Multimedia Commision. (2018), 'Internet users survey 2018: Statistical brief number twenty-three,' [Online], [Retrieved October 15, 2020], https://www.mcmc.gov.my/skmmgov my/media/General/pdf/InternetUsers-Survey-2018.pdf

- Ministry of Education Malaysia. (2014) E-learning Guidelines for Malaysian
HEIs, Department of Higher Education of Malaysia.

- My e-Learning World (2020), 'Schoology vs Edmodo vs Google Classroom - 3 education LMS comparison,' [Online], [Retrieved October 24, 2020], https://myelearningworld.com/school ogy-vs-edmodo-vs-google-classroom3-education-lms-comparison/

- National Center for Education Statistics. (2020), 'Enrollment,' [Online], [Retrieved October 24, 2020], https://nces.ed.gov/fastfacts/display.a sp?id=98

- $\quad$ Nieder, GL., Borges, NJ. and Pearson JC. (2011), 'Medical Student Use of Online Lectures: Exam Performance, Learning Styles, Achievement Motivation and Gender,' Med Sci Educator, 21 (3), 2226.

- Bernama. (2020), 'Online PdP safe way to avoid COVID-19 transmission - UPSI Vice Chancellor,' [Online], [Retrieved October 21, 2020], https://www.bernama.com/en/genera l/news.php?id=1892221

- Raaper, R and Brown, C. (2020), 'The Covid-19 pandemic and the dissolution of the university campus: Implications for student support practice,' Journal of Professional Capital and Community [Online], [Retrieved October 20, 2020], http://doi.org/ 10.1108/JPCC-062020-0032

- Soni, VD. (2020). Global Impact of eLearning during COVID 19. SSRN Electronic Journal, 12.

- $\quad$ Spickard, AI., Alrajeh, N., Cordray, D. and Gigante, J. (2002), 'Learning about Screening Using an Online or Live Lecture,' Journal of General International Medicine, 17 (7), 540-545.

- Tortorella, GL., Miorando, R., Fettermannand, D. and Mendoza, DT. (2020), 'An Empirical Investigation on Learning and Teaching Lean Manufacturing,' Education + Training, 62 (3), 339-354.

Faddliza MOHD ZAKI, Noor Masliana RAZLAN, Nurulannisa ABDULLAH Nurhidayah NASHARUDIN, Norhidayu MD YATIM, Noor Faraliza SAMSUDIN Jashira JAMIN and Intan Nurbaizura ZAINUDDIN, Journal of e-Learning and Higher Education, DOI: 10.5171/2021.145199 